\title{
ANALISIS RASIO PROFITABILITAS UNTUK MENGUKUR KINERJA KEUANGAN PADA PT. BANK PERKREDITAN RAKYAT BATARA WAJO MAKASSAR
}

\author{
Sartika \\ STIE LPI Makassar \\ sartika@gmail.com
}

\begin{abstract}
Abstrak,
Penelitian ini bertujuan untuk menguji analisis rasio profitabilitas, dalam menilai kinerja keuangan pada PT. Bank Perkreditan Rakyat Batara Wajo Makassar. Metode yang digunakan dalam penelitian ini adalah analisis deskriptif yaitu untuk menjelaskan tentang hasil perhitungan rasio profitabilitas, yang terjadi dalam perusahaan selama tahun 2016 sampai dengan 2018. Pengumpulan data dilakukan dengan teknik penelitian langsung dan dokumentasi. Populasi dalam penelitian ini adalah laporan keuangan PT. Bank Perkreditan Rakyat Batara Wajo Makassar selama tiga tahun terakhir (2016-2018) sekaligus menjadi sampel pada penelitian ini. Hasil penelitian menunjukkan bahwa PT. Bank Perkreditan Rakyat Batara Wajo Makassar selama tiga tahun terakhir mengalami kondisi yang tidak stabil atau tidak menetap, pengukuran kinerja keuangan dengan menggunakan rasio profitabilitas yang terdiri dari Return on Assets dinilai dalam keadaan yang tidak baik karena kemampuan aktiva yang diinvestasikan untuk berputar dalam menghasilkan laba yang tinggi kurang dan dengan Return on Equity dinilai dalam keadaan yang kurang baik karena kemampuan ekuitas/modal yang digunakan untuk menghasilkan laba sangat rendah..
\end{abstract}

Keywords: Kinerja Keuangan, Rasio Profitabilitas, Bank Perkreditan Rakyat.

\section{PENDAHULUAN / INTRODUCTION}

Perkembangan posisi keuangan mempunyai arti yang sangat penting bagi perusahaan. Untuk melihat sehat tidaknya suatu perusahaan tidak hanya dapat dinilai dari keadaan fisiknya saja, Misalnya dilihat dari gedung, pembangunan atau ekspansi. Faktor terpenting untuk dapat melihat perkembangan suatu perusahaan terletak dalam unsur keuangannya, karena dari unsur tersebut juga dapat mengevaluasi apakah kebijakan yang ditempuh suatu perusahaan sudah tepat atau belum, mengingat sudah begitu kompleksnya permasalahan yang dapat menyebabkan kebangkrutan dikarenakan banyaknya perusahaan yang akhirnya gulung tikar karena faktor keuangan yang tidak sehat.

Salah satu alat yang digunakan untuk mengetahui kondisi keuangan perusahaan dapat terwujudnya laporan keuangan. Laporan keuangan menyajikan mengenai posisi keuangan dari kinerja perusahaan dalam menghasilkan laba. Posisi keuangan perusahaan ditunjukkan dalam laporan posisi keungan (neraca), dalam laporan neraca kita dapat mengetahui kekayaan atau asets perusahaan yang dimiliki (sisi aktiva), dan dari sisi pasiva dapat kita ketahui dari mana dana-dana untuk membiayai aktiva tersebut (dari modal sendiri atau hutang), sedangkan kinerja perusahaan dalam menghasilkan laba dapat kita lihat dari laporan laba rugi perusahaan.

Muslich (2013:47) menyatakan bahwa "analisis rasio keuangan merupakan alat utama dalam analisis keuangan, karena analisis ini dapat digunakan untuk menjawab berbagai pertanyaan tentang keadaan perusahaan". Tujuannya adalah memberi gambaran mengenai kelemahan dan kemampuan financial /perusahaan dari tahun ke tahun. Analisis rasio ini akan 
sangat membantu dalam menilai prestasi manajemen di masa lalu dan prospeknya di masa yang akan datang.

Rasio keuangan (financial ratio) merupakan alat bantu yang dapat digunakan untuk menilai kondisi dan kinerja keuangan perusahaan maupun pegadaian. Menurut Loen (2018:119) " ada beberapa rasio yang bisa digunakan untuk menganalisis laporan keuangan, yaitu rasio profitabilitas, rasio likuiditas, rasio rentabilitas dan rasio solvabilitas". Analisis rasio profitabilitas dapat digunakan untuk mengetahui kemampuan perusahaan dalam menjalankan efektivitas manajemennya, yang ditunjukkan oleh laba yang dihasilkan.

Bank Perkreditan Rakyat (BPR) merupakan salah satu institusi keuangan formal yang mempunyai fungsi sebagai lembaga intermediasi keungan khususnya pada sistem keuangan mikro nasional. Keberadaan BPR telah terbukti sangat dirasakan manfaatnya bagi masyarakat golongan ekonomi kecil dan mikro karena mudah dijangkau oleh mereka. Meskipun saat ini hadir banyak institusi keuangan mikro baik bank maupun non bank, eksistensi BPR telah mendapatkan pengakuan dari masyarakat.

Bank memperoleh pendapatan dari bunga kredit yang disalurkan kepada masyarakat. Dengan penyaluran dana dalam bentuk kredit kepada masyarakat, bank juga dapat memperoleh pendapatan operasional maupun pendapatan non operasional. Bank juga bertujuan untuk mempertahankan kontinuitas bisnisnya yang dijalankannya selain untuk mendapatkan laba yang optimal. Maka salah satu syarat yang harus dipenuhi oleh bank yang sehat adalah sehatnya profitabilitas bank untuk menjamin kelangsungan hidup bank

\section{TINJAUAN TEORITIK / LITERATURE REVIEW}

\section{Kinerja Keuangan}

\section{Pengertian kinerja keuangan}

Kinerja perusahaan adalah suatu usaha formal yang dilaksanakan perusahaan untuk mengevaluasi efisien dan efektivitas dari aktivitas perusahaan yang telah dilaksanakan pada periode waktu tertentu. Menurut Sucipto (2016:34) "pengertian kinerja keuangan adalah penentuan ukuran- ukuran tertentu yang dapat mengukur keberhasilan suatu organisasi atau perusahaan dalam menghasilkan laba". Kinerja menurut Jumingan (2018:239) "Merupakan gambaran prestasi yang dicapai perusahaan dalam kegiatan operasionalnya baik menyangkut aspek kuangan, aspek pemasaran, aspek penghimpunan dana dan penyaluran dana, aspek teknologi, maupun aspek sumber daya manusianya". Sedangkan menurut IAI (2010:8) "Kinerja Keuangan adalah kemampuan perusahaan dalam mengelola dan mengendalikan sumberdaya yang dimilikinya".

\section{Tujuan kinerja keuangan}

Menurut Munawir (2017:31), tujuan penilaian kinerja keuangan adalah sebagai berikut: a. Untuk mengetahui tingkat likuiditas, yaitu kemapuan perusahaan untuk memperoleh kewajiban keuangannya yang harus segera dipenuhi atau kemampuan perusahaan untuk memenuhi keuangannya pada saat ditagih.

b. Untuk mengetahui tingkat solvabilitas, yaitu kemampuan perusahaan untuk memenuhi kewajiban keuangannya apabila perusahaan tersebut dilikuidasi baik kewajiban keuangan jangka pendek maupun jangka panjang.

c. Untuk mengetahui tingkat rentabilitas atau profitabilitas, yaitu menunjukkan kemampuan perusahaan untuk menghasilkan laba selama periode tertentu

d. Untuk mengtahui tingkat stabilitas usaha, yaitu kemampuan perusahaan untuk melakukan usahanya dengan stabil, yang dikur dengan mempertimbangkan kemampuan perusahaan 
untuk membayar beban bunga atas hutang-hutangnya termasuk membayar kembali pokok hutangnya tepat pada waktunya serta kemampuan membayar deviden secara teratur kepada para pemegang saham tanpa mengalami hambatan atau krisis keuangan.

\section{Hubungan kinerja keuangan dengan analisis laporan keuangan}

Tingkat kesehatan merupakan alat ukur yang digunakan oleh pemakai laporan keuangan untuk mengukur kinerja suatu laporan keuangan tersebut. Dari laporan keuangan dapat diketahui keadaan financial dari hasil -hasil yang telah dicapai perusahaan selama periode tertentu. Tingkat kesehatan perusahaan dapat dikeathui melalui analisis atau interpretasi terhadap laporan keuangan. Dari hasil analisis dapat diketahui presentasi dan kelemahan yang dimiliki perusahaan, sehinggat dapat digunakan sebagai pertimbangan dalam pengambilan keputusan. Inteterpretasi atau analisis laporan keuangan suatu perusahaan adalah sangat penting bagi pihak - pihak yang berkepentingan.

Secara umum Saraswati (2013:4) mengemukakan bahwa ada lima tahap dalam menganalisis kinerja keuangan suatu perusahaan yaitu:

a. Melakukan review terhadap data laporan keuangan.

b. Melakukan perbandingan terhadap hasil hitungan yang diperoleh.

c. Melakukan penafsiran (interpretasi) terhadap berbagai permasalahn yang ditemukan.

d. Mencari dan memberikan pemecahan masalah (solusi) terhadap berbagai permasalahan yang ditemukan.

Jadi dapat disimpulkan bahwa kinerja perusahaan yang tergambar dalam laporan keuangan yang menjadi perhatian utama bagi para pemakai laporan keuangan tersebut. Oleh karena itu manajemen perusahaan perlu mengusahakan untuk meningkatkan kinerja dari periode ke periode.

\section{Rasio Profitabilitas}

\section{Pengertian Profitabilitas}

Profitabilitas merupakan kempuan suatu perusahaan untuk mendapatkan laba (kenuntungan) dalam suatu periode tertentu. Pengertian yang sama disampaikan oleh Husnan (2012:72) bahwa profitabilitas adalah "rasio untuk mengukur efisiensi penggunaan aktiva perusahaan (atau mungkin sekelompok aktiva perusahaan)". Sartono (2010: 122), yang menyatakan bahwa "Profitabilitas adalah kemampuan perusahaan memperoleh laba dalam hubunganya dengan penjualan, total aktiva maupun modal sendiri". Sedangkan Menurut Kasmir (2012:196) menyatakan bahwa "rasio profitabilitas merupakan rasio untuk menilai kemampuan perusahaan dalam mencari keuntungan".

\section{Rasio Profitabilitas Sebagai Alat Pengukuran Kinerja Keuangan}

Menurut pendapat Shapiro (2019:731) Profitabilitas sangat cocok untuk mengukur efektivitas manajemen dan pengevaluasian kinerja manajemen dalam menjalankan bisnis dan produktivitasnya dalam mengelola aset-aset perusahaan secara keseluruhan seperti yang nampak pada pengembalian yang dihasilkan oleh penjualan dan investasi, serta untuk mengevaluasi kinerja ekonomi dari bisnis.

Secara umum profitabilitas merupakan pengukuran dari keseluruhan produktivitas dan kinerja perusahaan yang pada akhirnya akan menunjukkan efisiensi dan produktivitas perusahaan tersebut.

Tujuan penggunaan rasio profitabilitas bagi perusahaan, maupun bagi pihak luar perusahaan, yaitu; 
a. Untuk mengukur atau menghitung laba yang diperoleh perusahaan dalam satu periode tertentu.

b. Untuk menilai posisi laba perusahaan tahun sebelumnya dengan tahun sekarang.

c. Untuk menilai besarnya laba bersih sesudah pajak dengan modal sendiri.

d. Untuk mengukur produktivitas Untuk menilai perkembangan laba dari waktu ke waktu.

e. Seluruh dana perusahaan yang digunakan baik modal pinjaman maupun modal sendiri.

f. Untuk mengukur produktivitas dari seluruh dana perusahaan yang digunakan baik modal sendiri dan tujuan lainnya.

Sementara itu, manfaat yang diperoleh adalah untuk mengetahui besarnya tingkat laba yang diperoleh perusahaan dalam satu periode;

1) Mengetahui posisi laba perusahaan tahun sebelumnya dengan tahun sekarang.

2) Mengetahui perkembangan laba dari waktu ke waktu.

3) Mengetahui besarnya laba bersih sesudah pajak dengan modal sendiri.

4) Mengetahui produktivitas dari seluruh dana perusahaan yang digunakan baik modal pinjaman maupun modal sendiri.

\section{METODE PENELITIAN / METHODS}

\section{Jenis Penelitian}

Data yang dikumpulkan dalam penelitian ini adalah data kuantitatif. Data kuantitatif adalah data yang diperoleh dalam bentuk angka-angka seperti perencanaan dan laporan keuangan.

\section{Metode Analisis}

Untuk menguji sejauh mana kebenaran hipotesis yang dikemukakan diatas, maka metode yang digunakan dalam penelitian ini adalah kuantitatif, yang berupa angka-angka yang dapat diolah dengan matematika dan diuji secara statistic, yaitu laporan keungan perusahaan yang terdiri dari laporan neraca dan laba rugi PT. Bank Perkreditan Rakyat Batara Wajo Makassar. Adapun metode analisis yang digunakan antara lain:

a. Profit margin

Profit margin merupakan ukuran keuntungan dengan membandingkan antara laba setelah bunga dan pajak dibandingkan dengan penjualan. Rasio ini menunjukkan pendapatan bersih perusahaan atas penjualan.

Rumus yang digunakan adalah:

$$
\begin{aligned}
& \text { Net Profit Margin } \\
& (\text { Profit Margin On Sales })=\frac{\text { Net Profit After Tax }}{\text { Net Sales }} \times \\
& 1 \text { nnnt }
\end{aligned}
$$

Return on asset menggambarkan perputaran aktiva diukur dari volume penjualan. Semakin besar rasio ini semakin baik kinerja perusahaan dalam menghasilkan laba. Hal ini berarti bahwa aktiva dapat lebih cepat berputar dan meraih laba.

Rumus yang digunakan adalah:

$$
\text { Returnon Assets }=\frac{\text { Net } \text { Profit After Tax }}{\text { Total Assets }}
$$


Return on equity menggambarkan kemampuan perusahaan dalam memberikan pengembalian atas investasi para pemegang saham sehingga menunjukkan berapa persen diperoleh laba bersih bila menunjukkan berapa persen diperoleh laba bersih bila diukur dari modal pemilik. Semakin besar rasio ini semakin baik kinerja perusahaan dalam menghasilkan keuntungan bagi pemegang saham.

Rumus yang digunakan Adalah:

$$
\text { Return on Equity }=\frac{\text { Net Profit After Tax }}{\text { Equity }}
$$

\section{HASIL DAN PEMBAHASAN / DISCUSSION}

\section{Analisis Data}

\section{Return On Aset (ROA)}

Setelah melakukan analisis terhadap Laporan Neraca dan Laba Rugi Tahunan PT. BPR Batara Wajo dari tahun 2016 sampai dengan tahun 2018, ditemukan adanya perubahan volume profitabilitas atau laba yang diperoleh selama tiga tahun berturut-turut. Perubahan volume profitabilitas tersebut akan disajikan berdasarkan hasil perhitungan dengan menggunakan metode analisis yang telah disiapkan sebelumnya.

Tabel 1 Volume perubahan profitabilitas PT.BPR Batara Wajo Tahun 2016-2018

\begin{tabular}{|l|l|c|c|}
\hline Tahun & \multicolumn{1}{|c|}{ Laba Bersih } & Total Aset & $\begin{array}{c}\text { Return on } \\
\text { Asset ( \%) }\end{array}$ \\
\hline 2016 & Rp. 2.674 .000 & Rp. 4.060 .839 & $0.07 \%$ \\
\hline 2017 & Rp. (327.569) & Rp. 3.557.648 & $-0.09 \%$ \\
\hline 2018 & Rp. (131.243) & Rp 2.580.256 & $-0.05 \%$ \\
\hline
\end{tabular}

Sumber : Data diolah 2019

Dari tabel diatas, menunjukkan bahwa volume perubahan profitabilitas PT.BPR Batara Wajo pada umumnya mengalami penurunan dari tahun 2016-2018. Kondisi terburuk yang dialami oleh PT. BPR Batara Wajo adalah tahun 2018, dimana selain mengalami penurunan aset, juga mengalami kerugian atau tidak mendapatkan tingkat pengembalian aset (ROA). Adapun upaya yang berhasil dilakukan perusahaan pada tahun 2016 dalam meningkatkan usahanya, yaitu dengan bertambahnya jumlah aset dan mendapatkan laba sebesar Rp. 2.674,atau $0.07 \%$ dari total aset. Berdasarkan perhitungan dengan Metode ROA, Dapat dikatakan untung (laba). Namun bila dibandingkan dengan kerugian tahun 2017 dan 2018, laba tersebut masih jauh lebih kecil, atau dengan kata lain hanya dapat mengurangi jumlah kerugian yang dialami.

\section{Return On Equity (ROE)}

Adapun tingkat pengembalian ekuitas pemegang saham pada PT. BPR Batara Wajo yang disajikan pada laporan Neraca dan laporan laba rugi tahunan menunjukkan bahwa kemampuan perusahaan kurang maksimal. Hal ini terjadi akibat kurangnya profitabilitas yang dihasilkan dalam satu periode atau satu tahun anggaran.

Tabel 2 Persentase pengembalian investasi saham PT.BPR Batra Wajo tahun 20162018 


\begin{tabular}{|c|c|c|c|c|}
\hline No & Tahun & Laba bersih & Ekuitas & $\begin{array}{c}\text { Return on } \\
\text { Equity } \\
(\%)\end{array}$ \\
\hline 1 & 2016 & $2.674 .000,-$ & $1.941 .000,-$ & $1.38 \%$ \\
\hline 2 & 2017 & $(327.569)$ & $1.941 .000,-$ & $-0.17 \%$ \\
\hline 3 & 2018 & $(131.243)$ & 2.053 .000 & $-0.06 \%$ \\
\hline
\end{tabular}

Sumber : Data diolah 2019

Dari tabel diatas menunjukkan adanya pertambahan jumlah investasi saham pada tahun 2016 sebesar Rp. 1.941. 000,- dan tidak mengalami perubahan sampai tahun 2017. Di sisis lain, laba bersih yang dihasilkan selama tiga tahun PT. BPR Batara Wajo berdasarkan tahun 2016-2018 adalah sebagai berikut:

a. Tahun 2016

$$
\text { ROE }=\stackrel{2.674 .000,-}{1.941 .000-}
$$

b. Tahun 2017

$$
\text { ROE }=\frac{(327.569)}{1.941 .000,-} \text {--- } 100 \%=-0.17 \%
$$

c. Tahun 2018

$$
\text { ROE }=\frac{(131.243)}{2.053 .000} \text {----X } 100 \%=-0.06 \%
$$

\section{Net Profit Margin (NPM)}

Berdasarkan penelitian Laporan Neraca dan Laporan laba rugi Tahunan yang disajikan oleh PT.BPR Batara Wajo, Menunjukkan posisi volume usaha yang tidak stabil dari tahun 2016-2018.Untuk lebih jelasnya dapat dilihat pada tabel berikut:

Tabel 4.4 Persentase NPM PT. BPR Batra Wajo tahun 2016-2018

\begin{tabular}{|c|c|c|c|c|}
\hline No & Tahun & Laba Bersih & $\begin{array}{c}\text { Laba Oprasional } \\
\text { Bersih }\end{array}$ & $\begin{array}{c}\text { NPM } \\
(\%)\end{array}$ \\
\hline 1 & 2016 & $2.674 .000,-$ & $10.400 .000,-$ & $0.25 \%$ \\
\hline 2 & 2017 & $(327.569,-)$ & $(330.919,-)$ & $0.03 \%$ \\
\hline 3 & 2018 & $(131.243,-)$ & $(119.297,-)$ & $1.10 \%$ \\
\hline
\end{tabular}

Sumber : Data diolah 2019 
Dari tabel diatas terlihat jelas posisi keuangan yang mengalami penurunan pada tahun 2016 dan tahun 2017. Kondisi terburuknya adalah tahun 2017, dimana perusahaan menghasilkan laba $0.03 \%$.

Adapun perhitungan NPM PT. BPR Batara Wajo adalah sebagai berikut:

1.Tahun 2016

$$
\begin{aligned}
& \text { 2.674.000,- } \\
& \mathrm{NPM}=
\end{aligned}
$$

10.400.000,-

2.Tahun 2017

$$
\left.\mathrm{NPM}=\frac{(327.569,-)}{(330.919,-)} \text { - }\right)=0.03 \%
$$

3.Tahun 2018

$$
\text { NPM }=\frac{(131.243,-)}{(119.297,-)}
$$

\section{Pembahasan}

Hasil penelitian ini sekaligus juga menjawab pertanyaan yang keluar dari hipotesis penelitian yang ada di bab 2 antara lain : Diduga Diduga bahwa tingkat Rasio Profitabilitas pada PT. BPR Batara Wajo Makassar mengalami kondisi yang tidak stabil atau tidak menetap".

Berdasarkan hasil penelitian pada bab sebelumnya, ditemukan bahwa tingkat rasio profitabilitas PT.BPR Batara Wajo pada umumnya mengalami penurunan dari tahun 20162018. Kondisi terburuk yang dialami oleh PT. BPR Batara Wajo adalah tahun 2018, dimana selain mengalami penurunan aset, juga mengalami kerugian atau tidak mendapatkan tingkat pengembalian aset (ROA). Adapun upaya yang berhasil dilakukan perusahaan pada tahun 2016 dalam meningkatkan usahanya, yaitu dengan bertambahnya jumlah aset dan mendapatkan laba sebesar Rp. 2.674,- atau $0.07 \%$ dari total aset. Berdasarkan perhitungan dengan Metode ROA, Dapat dikatakan untung (laba). Namun bila dibandingkan dengan kerugian tahun 2017 dan 2018, laba tersebut masih jauh lebih kecil, atau dengan kata lain hanya dapat mengurangi jumlah kerugian yang dialami.

Adapun tingkat pengembalian ekuitas pemegang saham pada PT. BPR Batara Wajo yang disajikan pada laporan Neraca dan laporan laba rugi tahunan menunjukkan bahwa kemampuan perusahaan kurang maksimal. Hal ini terjadi akibat kurangnya profitabilitas yang dihasilkan dalam satu periode atau satu tahun anggaran.

Dari hasil analisis ROE sebelumnya menunjukkan adanya pertambahan jumlah investasi saham pada tahun 2016 sebesar Rp. 1.941. 000,- dan tidak mengalami perubahan sampai tahun 2017. Sedangkan hasil Net Profit Margin (NPM).

Berdasarkan penelitian Laporan Neraca dan Laporan laba rugi Tahunan yang disajikan oleh PT.BPR Batara Wajo, Menunjukkan posisi volume usaha yang tidak stabil dari tahun 20162018. terlihat jelas posisi keuangan yang mengalami penurunan pada tahun 2016 dan tahun 2017. Kondisi terburuknya adalah tahun 2017, dimana perusahaan menghasilkan laba $0.03 \%$. 


\section{KESIMPULAN / CONCLUSION}

\section{Simpulan}

1. Berdasarkan hasil analisis, menunjukkan bahwa tingkat profitabilitas pada PT.BPR Batara Wajo dari tahun 2016-2018 tidak mengalami peningkatan.

2. Hipotesis yang diungkapkan sebelumnya telah terbukti kebenarannya bahwa volume perkembangan usaha PT.BPR Batara Wajo selama tiga tahun berturur-turut mengalami kondisi yang tidak stabil atau tidak menetap.

\section{Saran}

Mengacu pada kesimpulan diatas, maka dapat diajukan beberapa saran sebagai berikut:

1. Perusahaan sebaiknya meningkatkan kinerja keuangannya dan berupaya meningkatkan laba perusahaan untuk tahun-tahun berikutnya.

2. Analisis penilaian kinerja perusahaan dilakukan tidak hanya berdasar data historis, tetapi dilakukan dengan analisa yang lebih mendalam mengenai aspek manajemen dan aspekaspek yang lain dari segi kualitasnya.

Diharapkan pada penelitian berikutnya yang akan membahas topik yang sama untuk memperluas ruang lingkup penelitiannya agar hasil yang didapat dalam menganalisis menjadi lebih akurat.

\section{DAFTAR PUSTAKA / REFERENCES}

Husnan, Suad. (2012). Dasar-Dasar Teori Portofolio. Edisi Tiga. Yogyakarta: UPP AMP YKPN.

Ikatan Akutansi Indonesia (IAI). 2010. Peryataan Standar Akuntansi Keuangan. Jakarta: Salemba Empat.

Jumingan. 2018. Analisis Laporan Keuangan. Jakarta: Bumi Aksara.

Kasmir, 2012. Analisis Laporan Keuangan, Rajawali Grafindo Persada, Jakarta. Loen, Boy. 2018. Manajemen Aktiva Pasiva Bank Devisa. Jakarta: PT. Grasindo.

Muslich, Mochammad.2013. Manajemen Keuangan Modern Analisis, Perencanaan dan Kebijaksanaan. Cetakan Ketiga. PT Bumi Aksara.Jakarta.

Munawir, 2017, Analisa Laporan Keuangan. Edisi Empat. Yogyakarta: PT Liberty.

Saraswati, Dinastya., Suhadak dan Siti Ragil Handayani. 2013. Analisis Laporan Keuangan Sebagai Alat Penilaian Kinerja Keuangan Pada Koperasi (Studi Pada Koperasi Universitas Brawijaya Malang Periode 2009 - 2012). Jurnal Administrasi Bisnis (JAB), $6(2): 1-20$.

Sartono, Agus. 2010. Manajemen Keuangan Teori dan Aplikasi. Edisi ke 4. Yogyakarta: BPFE.

Sucipto. 2016. Penilaian Kinerja Keuangan. Sumatra: Jurnal Digital Library Universitas Sumatra Utara. 
Sugiyono.2010. Metode Penelitian Kuantitatif, Kualitatif, dan R\&D: CV. Alfabet 